\title{
Kegelisahan dan ketidakpastian mantan narapidana dalam konteks komunikasi kelompok budaya Bugis Makassar
}

\author{
Tuti Bahfiarti \\ Universitas Hasanuddin, Makassar. Indonesia
}

\begin{abstract}
ABSTRAK
Stigma dan sanksi sosial mantan narapidana dalam budaya Bugis Makassar masih identik dengan nilai-nilai siri'. Mantan narapidana cenderung memiliki kegelisahan dan ketidakpastian dalam konteks komunikasi kelompok ketika proses interaksi awal. Identitas mantan narapidana menjadi faktor penghambat dalam berinteraksi dengan masyarakat Bugis Makassar. Tujuan penelitian untuk mengekplorasi, mengidentifikasi, dan mengkategorisasi pola kegelisahan dan ketidakpastian mantan narapidana dalam konteks komunikasi kelompok budaya Bugis Makassar. Pendekatan penelitian kualitatif mengacu pada studi kasus mantan narapidana yang secara psikologis mengalami kegelisahan dan ketidakpastian mulai interaksi awal dan interaksi langsung dengan masyarakat Bugis Makassar. Studi kasus berfokus pada mantan narapidana lakilaki dan perempuan dengan pola kejahatan yang berbeda. Hasil Penelitian mengidentifikasi kasus mantan narapidana yang cenderung tertutup berkomunikasi dalam kelompok Bugis Makassar. Pola kegelisahan dan ketidakpastian menyebabkan mantan narapidana menggunakan strategi mengurangi ketidakpastian yakni, strategi pasif (passive strategy) ditandai penarikan diri dan sikap pasif dan strategi aktif (active strategy) membuka diri dan aktif dalam berinteraksi dan berkomunikasi dalam kelompok budaya Bugis Makassar). Hasil penelitian bermanfaat bagi masyarakat Bugis Makassar untuk lebih terbuka, menghilangkan stigma negatif dan menerima identitas mantan narapidana dalam lingkungannya. Pihak Lembaga Pemasyarakatan dapat lebih mengintensifkan pola pembinaan dan persiapan mental narapidana ketika bebas dan menjalankan kehidupan bermasyarakat untuk lebih terbuka berinteraksi dalam kelompoknya.
\end{abstract}

Kata-kata Kunci: Mantan narapidana; komunikasi kelompok; kegelisahan; ketidakpastian; Bugis Makassar

\section{Anxiety and uncertainty of former prisoners : group communication context in Bugis Makassar culture}

\begin{abstract}
The stigma and social sanctions of former prisoners in the Bugis Makassar culture are still synonymous with siri'values. Former prisoners tend to have anxiety and uncertainty in the context of group communication when the initial interaction process. The identity of former prisoners is an inhibiting factor in interacting with the Bugis Makassar community. Research problems to explore, identify, and categorize the patterns of anxiety and uncertainty of former prisoners in the context of communication of the Bugis Makassar cultural group. The qualitative research approach refers to the case study of former prisoners who are psychologically experiencing anxiety and uncertainty from the initial interaction and direct interaction with the Bugis Makassar community. The research results idenfied the cases of former prisoners who tended to be closed in communication in the Makassar Bugis group. The pattern of anxiety and uncertainty causes former prisoners to use a strategy to reduce uncertainty, that is, a passive strategy that is characterized by withdrawal and passive attitudes and an active strategy to open up and be active in interacting and communicating within the Bugis Makassar cultural group. The results of the study are beneficial for the Bugis Makassar community to be more open, eliminate negative stigma and accept former prisoners in their environment. The Penitentiary can intensify the pattern of formation and mental preparation of prisoners when free and carry out community life to be more open to interact in their groups.
\end{abstract}

Keywords: Former Prisoners; group communication; anxiety; uncertainty; Bugis Makassar

Korespondensi: Dr. Tuti Bahfiarti, S.Sos. M.Si. Universitas Hasanuddin. Jl. Perintis Kemerdekaan KM 10 Kampus Tamalanrea Makassar 90245 Sulawesi Selatan. Telepon/Fax : 0411 585024.Email: tutibahfiarti@, unhas.ac.id. 


\section{PENDAHULUAN}

Dalam kehidupan bermasyarakat mantan narapidana cenderung berkonotasi negatif karena stigma penyakit sosial, khususnya dalam budaya Bugis Makassar. Hal ini disebabkan pelanggaran pidana dan perdata yang disangkakan. Sanksi sosial setelah identitas mantan narapidana menjadi hambatan untuk berinteraksi dalam kelompok masyarakat. Identitas narapidana adalah manusia memiliki hak asasi manusia, meskipun secara hukum telah divonis melakukan kejahatan (Coyle, 2009).

Pada dasarnya setiap manusia harus diperlakukan sebagai manusia, meskipun telah melakukan kesalahan. Lembaga Pemasyarakatan bukan hanya tempat memidana, namun membina dan mendidik narapidana untuk taat sebagai warga negara (Widayati, 2012). Narapidana harus diperlakukan secara manusiawi bukan sebagai penjahat. Sebaliknya, mantan narapidana harus menyadari bahwa dirinya dipandang dan diperlakukan sebagai manusia. Indikasi positif bagi masyarakat untuk menghargai mantan narapidana dalam proses interaksi sosial di lingkungan internal dan eksternalnya.

Mantan narapidana dalam proses interaksi sosial cenderung merasa terkucil karena prasangka negatif masyarakat. Penerimaan masyarakat yang berbeda sebelum dan setelah narapidana menjalani hukuman akibat vonis pengadilan. Misalnya, prasangka negatif masyarakat yang mempersepsi mantan narapidana sebagai manusia tidak berguna dan sampah masyarakat. Akibatnya, adaptasi diri mantan narapidana cenderung terhambat akibat persepsi negatif dan dikucilkan, khususnya kelompok masyarakat Bugis Makassar. Dalam budaya Bugis Makassar dikenal istilah siri' artinya rasa malu dan harga diri dari faktor kesalahan yang telah dilakukan.

Penelitian-penelitian narapidana menjelang tahun 1970-an berfokus pada kejahatan dan pemenjaraannya. Penelitian narapidana berawal dari asumsi lama bahwa kehidupan penjara laki-laki dan perempuan adalah sama. Studi Ward \& Kassebaum (1965) serta Giallombordo (1966) berfokus pada terbentuknya relasi sosial di penjara perempuan, khususnya homoseksualitas, seperti lesbian (Dynes \& Donaldson, 1992).
Perilaku menyimpang narapidana dianggap satu-satunya adaptasi perempuan terhadap deprivasi dan stres di penjara. Ironisnya ketika di penjara perempuan diputus dari hubungan suportif di luar penjara sehingga adaptasi diri narapidana perempuan biasanya membangun sebuah play families dan jaringan kekerabatan. Penerimaan diri positif pada narapidana perempuan berimplikasi positif pada dukungan keluarga inti, seperti orang tua dan saudara yang konsisten (Ardilla \& Herdiana, 2013).

Hasil kajian internal pada narapidana saat menjalani hukuman di penjara menurut Schmid \& Jones, yakni pemendaman identitas: transformasi identitas dalam penjara dengan penjagaan yang ketat (Mulyana \& Solatun, 2007). Melalui observasi partisipan selama 10 bulan dalam penjara dengan penjagaan sangat ketat di wilayah utara Midwest Amerika Serikat. Peneliti seorang tahanan menjalani hukuman satu tahun satu hari, peneliti lainnya berperan sebagai observasi non partisipan yang hanya mengamati dari luar. Hasil penelitian mengungkapkan identitas narapidana sebelum dipenjara, pengisolasian diri, pengelolaan kepribadian ganda, dialektika identitas dan identitas diri setelah bebas, serta model pemendaman identitas (Mulyana \& Solatun, 2007).

Penelitian pemendaman identitas: transformasi identitas dalam penjara dengan penjagaan ketat berfokus pada pengelolaan kesan (impression management) narapidana laki-laki di dalam penjara. Pengungkapan diri setelah bebas menjalani kehidupan di luar penjara kurang dieksplorasi dalam penelitian. Penelitian adaptasi diri tidak menemukan model representatif untuk narapidana dalam penjara. Kondisi narapidana saat menjalani kehidupan di dalam dan di luar penjara selalu ada kegelisahan dan ketidakpastian terhadap proses interaksi, khususnya lingkungan eksternal.

Hasilpenelitianterhadap mantannarapidana di Turki menemukan sikap negatif mantan narapidana memandang diri tidak bermanfaat dan putus asa berinteraksi dengan masyarakat. Aspek psiko-sosial, seperti pengucilan sosial, pelabelan dan kerugian, seperti pengangguran, masalah ekonomi, berakibat pada keluarga yang tinggalkan karena kesulitan berkomunikasi (Gorgulu, 2015).

Stigma negatif masyarakat mengakibatkan sikap pesimis dan putus asa dari mantan 
narapidana semakin tinggi. Berdasarkan hasil penelitian menyimpulkan bahwa permasalahan sosial, stigma dan diskriminasi yang menumbulkan ketidakpercayaan, kebencian, dan permusuhan (LeBel, 2012). Selanjutnya, hasil penelitian mengindikasikan bahwa ratusan tahanan yang dirilis setiap tahun menemukan adanya diskriminasi. Faktor diskriminasi menimbulkan sikap pesimis menjalani kehidupan sebagai mantan narapidana. Faktor ketakutan mantan narapidana setelah mulai berinteraksi dengan masyarakat menyebabkan tekanan psikologis dan kesulitan beradaptasi dengan masyarakat setelah keluar dari Lembaga Pemasyarakatan (Azani, 2012).

Penelitian narapidana telah dilakukan (Arfianti, 2006) yang meninjau dari aspek hukum secara spesifik mengkaji analisis kriminologi terhadap kejahatan kekerasan perempuan di Kota Makassar. Hasilnya faktor penyebab narapidana perempuan melakukan kejahatan, yakni pertama, faktor ekonomi, kedua, faktor emosi (kecemburuan sosial, masalah hubungan suami istri yang tidak mendapat perhatian dari suaminya. Ketiga, faktor malu atau 'siri', misalnya membunuh suaminya sendiri akibat rasa malu yang diterima. Fokusnya pada motif narapidana perempuan Bugis Makassar melakukan kejahatan hingga dipenjarakan. Lebih menarik hasil penelitian tersebut menyibak bahwa mereka justru melakukan kejahatan kerena mempertahankan harga diri siri' dalam masyarakat Bugis-Makassar masih dijunjung tinggi.

Faktor kegelisahan dan ketidakpastian dalam konteks komunikasi kelompok budaya Bugis Makassar yang masih memegang nilai siri' menyebabkan mantan narapidana takut memulai proses interaksi. Kecenderungan masyarakat Bugis Makassar mendiskreditkan atau menurunkan status narapidana sebagai individu yang tercemar dan diabaikan semakin meningkatkan stigma negatif. Dampak dari stigma sosial dan prasangka negatif menimbulkan kegelisahan dan ketidakpastian dalam diri mantan narapidana untuk memasuki hubungan sosial di lingkungan eksternalnya.

Penelitian ini berfokus pada kegelisahan dan ketidakpastian mantan narapidana dalam konteks komunikasi kelompok budaya Bugis Makassar. Kajian ini menjadi spesifik karena nilai ade siri' yang masih dipegang teguh masyarakat Bugis Makassar. Siri' dapat bermakna harkat dan martabat sebagai nilai budaya yang bersifat sentral dan inti kebudayaan Sulawesi Selatan. Dalam konteks budaya Bugis Makassar nilai paling berharga untuk dibela dan dipertahankan adalah siri'.

Budaya Bugis Makassar berprinsip lebih baik mati dalam mempertahankan harga diri (mate ri siri'na) daripada hidup tanpa rasa malu atau siri (mate siri'). Ketika harkat dan martabat diri dan keluarga jatuh (ripakasiri) karena dipermalukan maka mereka berkewajiban untuk membela dan menegakkan harga diri. Faktor keharusan adat, dengan cara memberikan hukuman adat kepada yang mempermalukan (mappakasiri'). Akibatnya, individu menerima sanksi sosial tidak dapat menahan tekanan adat sehingga menutup diri dengan lingkungan eksternalnya.

Siri' dalam diri mantan narapidana dan keluarganya berpotensi menimbulkan kegelisahan dan ketidakpastian. Proses interaksi awal dalam kelompok sosial masyarakat Bugis Makassar yang juga masih menjunjung tinggi nilai-nilai 'ade siri' menjadi penghambat untuk membuka diri dengan lingkungannya.

Penelitian ini bertujuan mengidentifikasi proses kegelisahan dan ketidakpastian mantan narapidana dalam konteks komunikasi kelompok budaya Bugis Makassar. Selanjutnya, mengkategorisasi pola kegelisahan dan strategi memasuki kelompok masyarakat yang juga memahaminilai-nilaisiri' dalamlingkungannya. Rasa malu tergambar dari konsekuensi akibat pelanggaran dan perbuatan melanggar hukum, norma dan budaya Bugis Makassar. Misalnya, kasus mantan narapidana dengan kelekatan nilai budaya 'ade siri' menyebabkan mereka cenderung tertutup untuk berinteraksi dengan lingkungan sekitarnya. Masyarakat Bugis Makassar masih memiliki stigma negatif akibat kejahatan yang disangkakan. Dalam masyarakat Bugis Makassar apabila seseorang dianggap gagal dan melanggar 'ade siri' maka akan dicap pengecut, tidak terhormat, tidak punya rasa malu, dan kehilangan harga dirinya (de'gaga siri'na) di mata masyarakat.

Konsep pemaknaan komunikasi antarmanusia sebagai suatu proses penciptaan makna antara dua orang atau lebih. Dalam komunikasi kelompok proses transaksi alamiah antara pengirim dan penerima pesan pada sekelompok individu untuk saling mengungkapkan makna. Komunikasi 
kelompok adalah komunikasi antara sejumlah orang yang memiliki tujuan atau keuntungan bersama di antara para anggotanya, biasanya terjadi pada lingkungan sosial (West \& Turner, 2009). Perilaku komunikasi dalam kelompok cenderung menyelesaikan tujuan-tujuan tertentu. Hal ini berarti bahwa kelompok merupakan individu-individu yang memiliki tujuan bersama, melakukan proses interaksi untuk mencapai tujuan bersama, saling menghargai, dan memandang mereka sebagai bagian dari kelompok tersebut.

Dalam proses interaksi komunikasi kelompok, terjadi interaksi simbolik yang memfokuskan tentang diri (self) oleh Mead merupakan suatu proses sosial, yakni "I" (Aku) dan "Me" (Daku). "I" adalah diri yang bersifat subjektif, diri yang refleksifyang mendefinisikan situasi dan merupakan kecenderungan impulsif individu untuk bertindak dalam suatu cara yang tidak terorganisasikan, tidak terarah, dan spontan sementara "Me" adalah pengambilan peran dan sikap orang lain termasuk kelompok tertentu. Konsep "I" dari Mead mirip dengan apa yang disebut Schutz "diri yang bekerja" (the working self) yakni diri melihat satu kesatuan yang utuh dan asal mula tindakan yang tengah berlangsung dalam kekinian yang jelas (modo presenti). Konsep "Me" dari Mead identik dengan Schutz sebut diri dalam sikap reflektif yang memandang kembali tindakan kerja yang dilakukan pada masa lalu (modo praeterito) (Mulyana, 2004).

Terdapat tiga hal penting bagi interaksionisme simbolik pertama, memusatkan perhatian pada interaksi antara aktor dan dunia nyata. Kedua, memandang aktor maupun dunia nyata sebagai proses dinamis dan bukan sebagai struktur yang statis. Ketiga, menghubungkan kemampuan aktor dalam menafsirkan kehidupan sosial (Ritzer \& Goodman, 2007). Dalam pengembangan teori identitas yang berangkat dari kerangka kerja para interaksionis simbolik dengan berkembangnya teori identitas yang menggabungkan konsep teori peran dan konsep diri (self concept) dari teori interaksi simbolik yakni definisi diri saat berinteraksi dan berkomunikasi dengan individu lainnya (Styker, 2000).

Intinya, teori interaksi simbolik dan identitas mendudukkan individu sebagai pihak yang aktif dalam menetapkan perilakunya dan membangun harapan-harapan sosial. Perspektif interaksionis yang beranggapan bahwa manusia adalah aktor dalam kehidupannya yang setiap peran ditampilkannya dalam berinteraksi dengan orang lain, memiliki definisi tentang diri yang berbeda dengan diri orang lain atau dinamakan "identitas". Peran yang dimainkan oleh setiap individu akan memainkan peran identitasnya, berarti bahwa semakin banyak peran yang dimainkan, maka semakin banyak identitas yang dimilikinya. Hal ini dipengaruhi oleh perilaku individu dalam melakukan suatu bentuk interaksi dengan orang lain.

Mantan narapidana memiliki identitas yang melekat dalam diri, sehingga dalam proses interaksi memiliki kegelisahan dan ketidakpastian akan identitas dirinya. Dalam teori Anxiety/Uncertainty Management (AUM) dianalisis William B. Gudykunst pertama tahun 1985 berfokus pada proses komunikasi efektif dalam kelompok. Pada tahun 1993 teori Anxiety/ Uncertainty Management (AUM) spesifik menganalisis proses penyesuaian diri dalam konteks komunikasi antarbudaya. Teori ini menekankan bahwa komunikator mengurangi kegelisahan dan ketidakpastian dalam kondisi individu yang berbeda budaya bertemu.

Teori Anxiety/Uncertainty Management (AUM)berdasarkanpemikiranteoripengurangan ketidakpastian yang dikembangkan Charles Berger dan teori identitas sosial Henri Tajfel. Asumsi dasar teori pengurangan ketidakpastian berfokus pada pengalaman kegelisahan (anxiety) dan ketidakpastian (uncertainty) ketika pertama kali bertemu dan berinteraksi dengan orang asing atau individu berbeda budaya. Gudykunst menganalisisi ketidakpastian (level kognitif) dan kegelisahan (level afektif). Gudykunst memberikan penjelasan bahwa uncertainty berfokus pada ketidakmampuan memprediksi atau menjelaskan perilaku, perasaan, sikap atau nilai orang lain. Anxiety berfokus pada perasaan ketidaknyamanan, kekhawatiran, emosional terhadap kejadian yang belum terjadi. Hal ini merupakan respon afektif (emosional), bukan respon kognitif seperti ketidakpastian" (Gudykunst \& Young, 1992). Teori AUM menyatakan mindfulness sebagai kemampuan seseorang dari sebuah individu atau kelompok mengurangi kegelisahan dan ketidakpastiannya.

Dalam konteks komunikasi antar kelompok individu mengalami krisis awal yakni kegelisahan, ketidakpastian, tidak aman, dan sulit menentukan sikap seperti yang 
dikembangkan oleh Charles Berger, William Gudykunts dan rekan-rekannya (Griffin, 2000). Teori-teori kegelisahan dan ketidakpastian mengajarkan pada diri individu untuk mengumpulkan informasi, memantau individu, lingkungan sosial melalui interaksi (Littlejohn \& Foss, 2011). Selanjutnya (Gudykunst \& Young, 1992) menggambarkan komunikasi sebagai "proses" dari pertukaran pesan dan penciptaan makna, bukan "hasil". Asumsinya bahwa komunikasi efektif ketika menafsirkan makna pada pesan relatif sama antara pengirim dan penerima pesan.

Teori AUM (Anxiety Uncertainty Management) (Gudykunst \& Young, 1992) dan pengurangan ketidakpastian karya Charles Berger merupakan teori yang menjadi rujukan peneliti dalam mengekplorasi, mengidentifikasi, dan mengkategorisasi. Kegelisahan/ ketidakpastian mantan narapidana dalam komunikasi kelompok konteks budaya Bugis Makassar. Dalam penelitian ini bagaimana mantan narapidana menjadi anggota suatu keompok berupaya mengurangi ketidakpastian pada tahap awal hubungan interaksi dengan kelekatan nilai-nilai siri'.

Dalam budaya Bugis Makassar yang tercantum dalam manuskrip 'Lontara' yang tertulis di atas daun lontara tertuang cara bersikap dan berperilaku yang dikenal dengan istilah pangngaderreng dan siri' (Mattulada, 1985). Istilah pangngaderreng dan siri yang mengatur pola pikir, tingkah laku, dan falsafah kehidupan bermasyarakat. Selanjutnya, dalam masyarakat Bugis terdapat konsepsi hukumhukum sosial (Mattulada, 1985) sebagai 'the sacred' pada masyarakat Bugis, yakni siri'. Budaya siri' merupakan tatanan berperilaku dalam masyarakat Bugis yang mengontrol, mengatur, dan mendasari segala perilaku dan perbuatan masyarakat. Siri' Orang BugisMakassar menghayati siri' itu sebagai panggilan yang mendalam dalam diri pribadinya, untuk mempertahankan nilai sesuatu yang dihormati, dihargai, dan dimilikinya (Mattulada, 1985).

James C. McCroskey dan koleganya sebagai Communication Apprehension (CA) mengacu pada kondisi yang membuat individu cenderung mengalami kecemasan saat berkomunikasi dengan orang lain. Menurut McCroskey dkk., Communication Apprehension (CA) merupakan persoalan serius yang dihadapi oleh banyak orang. Individu dengan tingkat Communication Apprehension (CA) tinggi lebih sering mengalami kesulitan dalam interaksi sosial, sebaliknya individu dengan tingkat Communication Apprehension (CA) rendah lebih mudah dalam interaksi sosial. Communication Apprehension (CA) bisa merupakan sifat (trait) atau keadaan (state). Teori kecemasan berkomunikasi (communication apprehension) memposisikan mantan narapidana memiliki kegelisahan dan ketidakpastian dalam berkomunikasi dengan lingkungan eksternalnya (Mccroskey, 1982).

Faktor kegelisahan dan ketidakpastian mantan narapidana menjadi spesifik untuk dikaji karena penelitian terdahulu lebih dominan menggambarkan tingkat depresi dan terapi pada narapidana saat menjalani hukuman. Hal ini seperti hasil penelitian (Wuryansari \& Subandi, 2019) terhadap program minsfulness narapidana dalam upaya menurunkan depresi di dalam tahanan.

Penelitian-penelitian terdahulu lebih berfokus ke psikologis narapidana, antara lain (Sari, Wati, \& Rahmawaty, 2014) menganalisis tingkat depresi narapidana kategori non residivis dan residivis di dalam tahanan. Selanjutnya, secara spesifik mengkaji gangguan kejiwaan yang dialami narapidana laki-laki yang depresi dan mencoba melakukan tindakan bunuh diri yang mengancam jiwa dan keselamatannya. Fokus penelitian studi kasus narapidana lakilaki dari aspek psikologisnya (Rivlin, Hawton, Marzano, \& Fazel, 2010).

Penelitian pada mantan narapidana perempuan dalam stigma ketidakadilan dalam masyarakat Surabaya cenderung dialami, seperti perlakuan negatif. Mereka dianggap sebagai perempuan cacat sosial karena kejahatan yang pernah dilakukan. Bentuk tindakan distereotipe, disubordinasi, dimarginalisasi dari masyarakat di lingkungan eksternalnya. Lingkungan tempat tinggal baru yang menghindarkan mantan narapidana perempuan dari perlakukan dan stigma negatif berpotensi mereka lebih terbuka dalam kehidupannya (Kurniawati, 2016).

Perbedaan dengan penelitian ini adalah identitas mantan narapidana dan melalui proses interaksi dan komunikasi dengan masyarakat Bugis Makassar yang masih menganut kelekatan nilai-nilai ade' siri'. Identitas diri mantan narapidana dalam bermasyarakat, berinteraksi, dan berkomunikasi langsung dengan lingkungan ekternal yang masih memiliki stigma dan 
sanksi sosial dapat berpotensi negatif dalam diri mantan narapidana tersebut. Untuk itu, penelitian ini berfokus mengungkapkan dengan mengkategorisasi kegelisahan dan ketidakpastian mantan narapidana dalam budaya Bugis Makassar.

Konseptual dan teoritikal merupakan panduan dalam menjawab fokus permasalahan penelitian, pertama: bagaimana pola kegelisahan dan ketidakpastian mantan narapidana dalam konteks komunikasi kelompok budaya Bugis Makassar. Kedua, bagaimana hambatan internal dan eksternal mengurangi kegelisahan dan ketidakpastian mantan narapidana dalam konteks komunikasi kelompok budaya Bugis Makassar. Fokus permasalahan penelitian tersebut bertujuan mengeksplorasi, mengkategorisasi, dan menganalisis kegelisahan dan ketidakpastian mantan narapidana dalam konteks komunikasi kelompok budaya Bugis Makassar.

\section{METODE PENELITIAN}

Penelitian kegelisahan dan ketidakpastianmantannarapidana dalamkonteks komunikasi kelompok budaya Bugis Makassar menggunakan metode kualitatif. Kasus mantan narapidana memiliki realitas subjektif untuk menemukan kebenaran dibalik keteraturan, khususnya nilai-nilai ade siri' dalam konteks masyarakat Bugis Makassar. Secara sistematis penelitian ini bertujuan mengeksplorasi teori dari fakta dunia nyata berdasarkan fenomena yang telah dieksplorasi. Pendekatan studi kasus bertujuan untuk mengontrol peristiwa-peristiwa yang akan diselidiki dan fokus penelitian terletak pada fenomena dalam konteks kehidupan nyata" (Yin, 2008). Studi kasus melibatkan peneliti dalam penyelidikan lebih spesifik dan melakukan identitifikasi keseluruhan dari setiap tindakan dan perilaku aktor yang diteliti (Yin, 2008).

Penelitian studi kasus peneliti melakukan ekplorasi mendalam terhadap kisah hidup individu atau kelompok melalui kasus yang variatif (Creswell, 2014). Pengumpulan data lapangan dilakukan secara mendalam serta melibatkan sumber informasi yang kredibel terhadap kasus tersebut, seperti observasi langsung, wawancara mendalam, serta deskripsi kasus yang diteliti (Makmur, Kuswarno, Novianti, \& Syafirah, 2018).
Subjek penelitian ini adalah mantan narapidana berjenis kelamin laki-laki dan perempuan beretnik Bugis Makassar. Penentuan informan dilakukan melalui non-probability sampling/non-random yaitu purposive sampling. Purposive sampling merupakan penarikan informan yang didasarkan pada syarat dan kriteria-kriteria yang ditentukan oleh peneliti sesuai dengan permasalahan penelitian. Syarat dan kriteria informan adalah: pertama, informan dengan identitas mantan narapidana berjenis kelamin laki-laki dan perempuan. Kedua, informan telah berinteraksi langsung lebih dari satu bulan dengan masyarakat Bugis Makassar. Ketiga, mantan narapidana etnik Bugis Makassar yang masih memiliki kelekatan nilai ade' 'siri' yang dimaknai sebai harga diri atau rasa malu dalam diri kehidupan mereka. Keempat, jenis-jenis pelanggaran hukum pidana, seperti perkelahian/penganiayaan, pencurian, penggelapan/penipuan, penadah, dan Narkotika dan Obat-obatan Terlarang. Kelima, informan yang bersedia memberikan jawaban yang akurat dan representatif sesuai dengan masalah dan tujuan penelitian.

Objek penelitian ini berfokus pada kegelisahan dan ketidakpastian mantan narapida dalam konteks komunikasi kelompok budaya Bugis Makassar. Teknik pengumpulan data penelitian, pertama; observasi nonpartisipan, yakni peneliti tidak terlibat langsung mengamati rutinitas subjek penelitian dalam konteks komunikasi kelompok budaya Bugis Makassar. Misalnya, perilaku informan mulai dari perkenalan awal interaksi sampai akhir interaksi. Kategori peneliti sebagai pengamat dapat mempresentasikan situasi yang memungkinkan peneliti melakukan sekali kunjungan atau wawancara dengan responden dan pengamat penuh (complete observer) yang tidak melibatkan interaksi sosial. Kedua, wawancara mendalam sebagai suatu proses untuk memperoleh keterangan dengan cara tanya jawab secara langsung dengan informan seperti pandangan (Denzin \& Lincoln, 2009).

Interaksi langsung antara peneliti dengan informan atau memiliki keterlibatan tinggi dalam kehidupan informan. Ketiga, kepustakaan berupa sumber-sumber buku, jurnal, cerita-cerita rakyat Bugis-Makassar seperti yang terurai dalam sastra Bugis klasik, meliputi Sure La Galigo (yang dikenal sebagai epik terpanjang di dunia), Lontarak, Paseng/ 
Tabel 1 Karakteristik Informan

\begin{tabular}{cccc}
\hline No & $\begin{array}{c}\text { Informa } \mathrm{n} \text { J } \mathrm{J} \text { n i s } \\
\text { M a n t a } \\
\text { Narapidana }\end{array}$ & $\begin{array}{c}\text { Umur } \\
\text { Kelamin }\end{array}$ & (Tahun) \\
\hline 1 & Ifa & Perempuan & 55 \\
2 & Dewi & Perempuan & 35 \\
3 & Rina & Perempuan & 40 \\
4 & Besse & Perempuan & 30 \\
5 & Kebo & Perempuan & 27 \\
6 & Anwar & Laki-Laki & 30 \\
7 & Baso & Laki-Laki & 23 \\
8 & Aco & Laki-Laki & 31 \\
9 & Ali & Laki-Laki & 27 \\
10 & Rusli & Laki-Laki & 25 \\
\hline
\end{tabular}

Sumber : Hasil Penelitian, 2019

Pappaseng, Toriolota/ Ungkapan, dan Elong/ Syair mengandung kearifan budaya Bugis Makassar, dan Latoa karya (Mattulada, 1985).

Teknik analisis data menggunakan prosedur analisis data perspektif Miles dan Huberman yang dikenal dengan model analisis data interaktif, antara lain: pertama, reduksi data merupakan proses penilaian, pemusatan, dan penyederhanaan, serta transformasi data dari catatan tertulis hasil observasi non partisipan dan wawancara mendalam pada subjek pada mantan narapidana. Tahapan ini mengarahkan dan menajamkan analisis dengan mereduksi dan menyaring data-data berdasarkan objek penelitian. Hasil reduksi data mengumpulkan data-data yang relevan dengan kegelisahan dan ketidakpastian mantan narapida dalam konteks komunikasi kelompok budaya Bugis Makassar.

Selanjutnya, kedua adalah tahapan penyajian data merupakan hasil reduksi data telah disajikan secara sistematis dan memiliki keterkaitan logis. Penyajian data dapat dilakukan dalam bentuk gambar, matriks, skema, alur, tabel yang didesain secara representatif. Cara ini memudahkan peneliti menyajikan hasil data penelitian. Ketiga, menarik kesimpulan atau memverifikasi data-data yang telah dikumpulkan dan dianalisis. Hasil data yang telah disimpulkan melalui proses validitasi datadata yang valid dan konsistensi. Tahap verifikasi bertujuan menghindari bias pemahaman peneliti terhadap data-data yang dikumpulkan melalui pengujian validitas data (Miles, Huberman, \&
Saldana, 2015).

\section{HASIL DAN PEMBAHASAN}

Penelitian kegelisahan dan ketidakpastian mantan narapida dalam konteks komunikasi kelompok budaya Bugis Makassar menggunakan pendekatan studi kasus. Fokus penelitian dalam konteks kehidupan nyata melibatkan peneliti dalam penyelidikan, sehingga perilaku individu dapat diamati ketika berinteraksi dalam kelompok masyarakat Bugis Makassar. Budaya siri' menjadi kelekatan nilai dalam masyarakat Bugis Makassar yang masih memegang kearifan lokal dalam kehidupan bermasyrakat. Berdasarkan hasil penelitian menemukan dan mendeskripsikan identitas diri sepuluh mantan narapidana, yakni 5 mantan narapidana laki-laki dan 5 mantan narapidana perempuan yang berperan sebagai informan. Tabel 2, mendeskripsikan identitas diri informan.

Berdasarkan karakteristik informan Ifa (bukan nama sebenarnya) berumur 55 tahun etnik Bugis Pangkajene Kepulauan. Ifa memiliki sembilan orang anak mengaku dua kali masuk penjara karena fitnah dari rekan kerja sesama pedagang. Semangat pekerja keras dan jiwa pemberani orang Bugis yang suka merantau dan berdagang juga mengalir dalam tubuhnya. Ifa berdagang antara Makassar dan Samarinda, namun pada suatu ketika sebagian

\section{Tabel 2 Jenis Pelanggaran Informan}

\begin{tabular}{ccc}
\hline No & $\begin{array}{c}\text { Nama Mantan } \\
\text { Narapidana }\end{array}$ & Jenis Pelanggaran \\
\hline 1 & Ifa & P e n g g e l a p a n / \\
2 & Dewipuan \\
3 & Rina & Narkoba \\
4 & Besse & Nenadah \\
5 & Kebo & Narkoba \\
6 & Anwar & narkoba \\
7 & Baso & narkoba \\
8 & Aco & Pencurian \\
9 & Ali & P e n g g e l a p a n / \\
& & Penipuan \\
10 & Rusli & Narkoba \\
\hline
\end{tabular}

Sumber : Hasil Penelitian, 2019 
besar pelanggannya tidak membayar barang yang dibawanya, tidak sanggup membayar, kemudian dilaporkan ke polisi. Ifa menggunakan bahasa Bugis kental dengan dialek Pangkajene Kepulauan menceritakan kisahnya keluar masuk penjara sebanyak dua kali tahun 2007 dan tahun 2013 dengan tuduhan penggelapan.

Informan Kedua bernama Dewi (bukan nama sebenarnya) berdasarkan petunjuk alamat di Lembaga Pemasyarakatan bertempat tinggal di Sungguminasa Gowa. Dewi yang berumur 35 tahun tinggal di rumah mertua dan empat orang anaknya. Ibu dari dua anak ini berstatus janda karena suaminya meninggal dunia. Pekerjaan Dewi saat ini adalah berdagang dari rumah ke rumah dan teman-teman lama. Wanti yang etnik Bugis Pangkajene Kepulauan masuk Lembaga Pemasyarakatan saat suaminya masih hidup tahun 2000. Kasus pertama yang dialaminya karena keinginan membantu kesembuhan suaminya yang jatuh sakit untuk mencari nafkah bagi keempat orang anaknya. Wanti diajak temannya mengambil baju sampai akhirnya digerebek polisi. Wanti tertangkap dan dinyatakan bersalah. Meskipun, tidak mengetahui jika barang dagangan tersebut adalah hasil curian. Akhirnya, Wanti terjerat pasal penadah hasil curian dengan ancaman enam bulan kurungan penjara.

Informan ketiga bernama Rina (bukan nama sebenarnya) yang secara tidak sengaja satu sel penjara dengan informan kelima bernama Kebo (bukan nama sebenarnya). Keduanya menjadi narapidana akibat sangkaan pelanggaran Narkotika dan Obat-obatan terlarang. Rina saat ini bermur 40 tahun memiliki tubuh gemuk, rambut ikal panjang diikat terlihat sangat tomboy, selalu tampil dengan busana jeans dan kaos oblong, dan rokok yang dengan santai diisapnya. Dengan gaya humorisnya Anti yang santai mengatakan bahwa dirinya sudah menerima keadaan dirinya sebagai mantan narapidana perempuan, hanya terkadang masyarakat sekitar yang masih belum mempercayainya jika dirinya telah berubah.

Informan kelima bernama Besse (bukan nama sebenarnya) gadis keturunan bangsawan Sengkang yang mengaku tinggal di Kota Makassar bekerja distro pakaian. Penampilan Besse sederhana dan pemalu. Sejak bermur 20 tahun, Besse meninggalkan Sengkang Kota kelahirannya ke Makassar untuk mencari nafkah. Besse terjerat kasus penadah barang hasil curian yang dilakukan temannya sendiri. Temannya meminta tolong menyimpan televisi ukuran 21 inci yang dititipkan rumah kosnya. Namun, setelah dua minggu rumah kosnya didatangi oleh sekelompok polisi yang mengaku mencari televisi 21 inci tersebut.

Mantan narapidana berjenis kelamin lakilaki yang dipilih sebanyak 5 orang. Informan kelima, keenam, dan kesepuluh bernama Anwar, Baso, dan Rusdi memiliki jenis pelanggaran yang sama yakni: Narkotika dan obat-obatan terlarang. Ketiga informan mantan narapidana melakukan kejahatan karena faktor ekonomi dan juga faktor lingkungan. Mereka merupakan mantan narapidana residivis yang melanggar pasal 112 ayat 1 Undang-Undang Nomor 35 Tahun 2009 tentang Narkotika.

Selanjutnya kegelisahan dan ketidakpastian mantan narapidana dalam konteks komunikasi kelompok budaya Bugis Makassar yang masih menjunjung tinggi nilai-nilai siri' dalam kehidupannya. Kegelisahan dan ketidakpastian mantan narapidana faktor utama kegagalan komunikasi kelompok dalam budaya Bugis Makassar. Pola kegelisahan mantan narapidana dan karakteristiknya, seperti Tabel 3.

Proses interaksi dengan individu dalam suatu kelompok budaya dianggap sebagai situasi baru (novel situation) setelah bertatus mantan narapidana. Situasi baru dalam kelompok masyarakat yang dulu mengenalnya tetap sebagai menimbulkan tingkat kegelisahan dan ketidakpastian yang tinggi. Faktor kegelisahan dan ketidakpastian dalam diri mantan narapidana. Faktor kegelisahan mengindikasikan perasaan khawatir, tegang, cemas, takut, rendah diri, tidak percaya diri terhadap penerimaan ketika memasuki kelompok masyarakat Bugis Makassar. Faktor ketidakpastian mengindikasikan ketidakmampuan mereka memprediksi perilaku positif dan negatif, respons, sikap, atau stigma sosial dalam kelompok masyarakat Bugis Makassar.

Berdasarkan hasil eksplorasi dan kategorisasi penelitian ditemukan bahwa pola ketidakpastian mantan narapidana dalam konteks komunikasi kelompok budaya Bugis Makassar menimbulkan hambatan dan kegagalan berkomunikasi dalam kelompok karena kelekatan nilai-nilai siri' dalam diri mantan narapidana dan masyarakat Bugis Makassar, seperti Tabel 4. 
Tabel 3 Pola Kegelisahan Mantan Narapidana dan Karakteristiknya

\begin{tabular}{ll}
\hline Pola Kegelisahan & $\begin{array}{l}\text { Karakteristik Kegelisahan Mantan Narapidana Dalam Konteks } \\
\text { Komunikasi Kelompok }\end{array}$ \\
\hline Kegelisahan Internal & $\begin{array}{l}\text { a. Kehilangan kepercayaan diri sehingga sulit berinteraksi langsung } \\
\text { dengan kelompok masyarakat Bugis Makassar. } \\
\text { b. Rendah diri sehingga memilih menyembunyikan identitasnya pada } \\
\text { kelompok masyarakat yang baru dikenalnya. } \\
\text { c.Berpikir negatif karena perasaan siri’ yang dimiliki sehingga ada } \\
\text { kegelisahan tidak diterima dan dihargai dalam masyarakat. } \\
\text { Kegelisahan }\end{array}$ \\
& $\begin{array}{l}\text { a. Penolakan sosial dari kelompok masyarakat Bugis Makassar } \\
\text { narapidana. }\end{array}$ \\
& $\begin{array}{l}\text { c. Ketakutan perubahan identitas baru karena identitas mantan } \\
\text { narapidana masih dianggap negatif dalam budaya Bugis Makassar }\end{array}$ \\
\hline
\end{tabular}

Sumber : Hasil Penelitian, 2019

Kegelisahan mantan narapidana berasal dari luar individu merupakan bentuk penolakan sosial, dan situasi yang mengancam proses adaptasi awal individu dalam kelompok masyarakat. Bentuk kegelisahan eksternal, seperti penolakan sosial dan stigma sosial yang cenderung negatif dari kelompok masyarakat Bugis Makassar. Ketakutan perubahan indentitas baru sebagai mantan narapidana menyebabkan mereka memilih untuk diam dalam interaksi kelompok sosial. Faktor ini menyebabkan mantan narapidana kurang terbuka berkomunikasi masih dalam kelompok akibat perasaan takut ditolak dalam budaya Bugis Makassar.

Bentuk kegelisahan internal menyebabkan

Tabel 4 Pola Ketidakpastian Mantan Narapidana dan Karakteristiknya

\begin{tabular}{|c|c|}
\hline Pola Ketidakpastian & $\begin{array}{l}\text { Karakteristik Ketidakpastian Mantan Narapidana Dalam Konteks } \\
\text { Komunikasi Kelompok }\end{array}$ \\
\hline \multirow[t]{3}{*}{ Ketidakpastian Internal } & $\begin{array}{l}\text { a. Menghindari dan meminimallkan kontak komunikasi dengan } \\
\text { anggota kelompok dalam masyarakat Bugis makassar }\end{array}$ \\
\hline & $\begin{array}{l}\text { b. Perilaku positif atau negatif ditunjukkan saat berkomunikasi, } \\
\text { atau respons dari orang lain. }\end{array}$ \\
\hline & $\begin{array}{l}\text { c. Mengambil posisi diam untuk menghindari prasangka } \\
\text { negatif. }\end{array}$ \\
\hline \multirow{5}{*}{$\begin{array}{l}\text { Ketidakpastian } \\
\text { Eksternal }\end{array}$} & a. Kelompok masyarakat menarik diri dan menghindari \\
\hline & pergaulan karena faktor siri' masiri' atau faktor malu. \\
\hline & b. Merespon dunia luar dengan terbuka \\
\hline & $\begin{array}{l}\text { c. Ketidakpastian penerimaan perilaku negatif yang diterima di } \\
\text { masyarakat Bugis makassar }\end{array}$ \\
\hline & $\begin{array}{l}\text { d. Berperilaku sopan, bertegur sapa, tersenyum, tampilan } \\
\text { perilaku positif, konsep diri positif dengan identitas yang } \\
\text { melekat dalam diri. }\end{array}$ \\
\hline
\end{tabular}

Sumber : Hasil Penelitian, 2019 
mantan narapidana kehilangan kepercayaan diri, rendah diri, dan orientasi berpikir negatif akan penolakan yang berpotensi diterima sehingga sulit berinteraksi langsung dengan kelompok masyarakat Bugis Makassar. Akibatnya mantan narapidana memilih menyembunyikan identitasnya pada kelompok masyarakat yang baru dikenalnya.

Kegelisahan secara psikologis menghambat proses komunikasi mantan narapidana dengan budaya Bugis Makassar yang nilai-nilai adat siri' masih digunakan filosofi kehidupan bermasyarakat. Siri' merupakan filosofi bermakna positif untuk berbuat kebajikan dan tidak melanggar aturan bermasyarakat. Akibatnya, timbul kegelisahan dalam diri individu yang tidak dapat menahan tekanan adat mengakibatkan mereka cenderung menutup diri dengan lingkungan eksternalnya.

Selanjutnya, ketidakpastian mantan narapidana menyebabkan terjadinya penghindaran diri terhadap kelompok sosial, bahkan meminimalkan kontak komunikasi dari masyarakat Bugis Makassar. Hal ini menyebabkan orientasi perilaku negatif saat berkomunikasi, atau memilih berdiam diri di lingkungan eksternal sehingga prasangka negatif dan siri' dalam diri dan keluarga. Ketidakpastiaan eksternal yang dialami mantan narapidana adalah ketakutan kelompok masyarakat menarik diri dan menghindari pergaulan karena faktor siri' masiri' atau faktor malu dari masyarakat Bugis Makassar. Faktor lainnya disebabkan oleh ketidakpastian penerimaan perilaku negatif yang diterima di masyarakat Bugis Makassar. Strategi aktif yang dilakukan adalah merespon dunia luar dengan terbuka, berperilaku sopan, menyapa, tersenyum, menjaga perilaku, percaya diri, dan lebih terbuka meskipun identitas yang melekat dalam diri sebagai mantan narapidana.

Hasil penelitian menunjukkan tingkatan kegelisahan dan ketidakpastian tinggi utamanya pada awal keluar dari penjara. Hasil penelitian mengasumsikan bahwa tingkat kegelisahan dan ketidakpastian sangat tinggi. Artinya bahwa semakin tinggi tingkat kegelisahan dan ketidakpastian maka mantan narapidana memilih diam dan mengambil strategi pasif. Sebaliknya semakin rendah tingkat kegelisahan dan ketidakpastian maka mantan narapidana lebih bersikap terbuka dengan kelompok masyarakat dan memilih strategi aktif. Caranya
Tabel 5 Asumsi Tingkatan Kegelisahan dan

Ketidakpastian Mantan Narapidana

\begin{tabular}{lll}
\hline Asumsi Tingkatan & Strategi & Mantan \\
Kegelisahan dan Narapidana & \\
Ketidakpastian & & \\
\hline \multicolumn{1}{l}{ Tingkat Kegelisahan } & Pasif dan & Menarik \\
dan Ketidakpastian & Diri & \\
Tinggi & & \\
Tingkat Kegelisahan Aktif dan & Membuka \\
dan Ketidakpastian Diri & \\
Rendah & & \\
\hline
\end{tabular}

Sumber : Hasil Penelitian, 2019

adalah membuka diri lebih awal agar diterima dalam lingkungan kelompok masyarakat Bugis Makassar, seperti Tabel 5.

Asumsi tingkatan kegelisahan dan ketidakpastian mantan narapidana dapat didasarkan pada gagasan teoritik ketidakpastian dan kecemasan dalam berkomunikasi yang dikembangkan James C. McCroskey dan koleganya sebagai Communication Apprehension (CA) (Mccroskey, 1982) Communication Apprehension (CA) mengacu pada kondisi yang membuat individu cenderung mengalami kecemasan saat berkomunikasi dengan orang lain. Menurut McCroskey dkk. Communication Apprehension (CA) juga dialami oleh mantan narapidana karena kelekatan nilai ade siri ' dalam diri mantan narapidana.

Tingkat Communication Apprehension (CA) sangat tinggi, akibatnya individu mengalami kesulitan dalam interaksi sosial. Tingginya kecemasan komunikasi menimbulkan kekhawatiran jika orang lain tidak merespons percakapan atau kontak yang mereka lakukan. Akibatnya, mantan narapidana lebih memiliki diam (silent) untuk memulai percakapan atau kontak awal interaksi. Sebaliknya, mantan narapidana yang memiliki tingkat Communication Apprehension (CA) rendah lebih terbuka dalam interaksi sosial dan kerelaan memasuki kelompok sosial. Rendahnya kecemasan komunikasi menimbulkan keterbukaan dalam memulai respons percakapan atau kontak awal di lingkungan eksternalnya. Akibatnya, mantan 
narapidana lebih memiliki keaktifan dalam berkomunikasi untuk memulai percakapan atau kontak awal interaksi.

Littlejohn \& Foss, (2011) menyebutkan bahwa teori pengurangan ketidakpastian yang dikembangkan Berger Calabrese menjelaskan bagaimana seseorang berkomunikasi ketika berada dalam lingkungan sosial yang tidak pasti. Menurut Berger, orang mengalami ketidakpastian ketika berinteraksi dan mencoba untuk mengurangi ketidakpastian tersebut (Morissan, 2009). Teori pengurangan ketidakpastian merupakan ketidakmampuan individu untuk memprediksi atau menjelaskan perilaku diri sendiri atau orang lain.

Mantan narapidana dalam kelompok sosial masyarakat Bugis Makassar memiliki ketidakpastian kognitif (cognitive uncertainty) dan ketidakpastian perilaku (behavioral uncertainty). Ketidakpastian kognitif mantan narapidana akibat rendahnya kepercayaan diri karena identitas negatif yang dipersepsikan dalam masyarakat Bugis Makassar. Ketidakpastian perilaku dalam diri mantan narapidana akibat ketidakyakinan sikap diri dan sikap orang lain. Hal ini disebabkan mantan narapidana dan masyarakat Bugis Makassar memiliki kelekatan nilai siri' dalam diri mereka. Dari sisi mantan narapidana memiliki rasa malu terhadap identitas yang dimiliki sedangkan masyarakat Bugis Makassar memiliki stigma negatif terhadap mantan narapidana yang baru menjalani proses pembinaan di Lembaga Pemasyarakatan.

Dalam kasus mantan narapidana yang memiliki kelekatan nilai ade 'siri' pengurangan ketidakpastian memiliki motivasi untuk mengurangi ketidakpastian berdasarkan tiga syarat, yakni insentif, deviasi/ penyimpangan, dan antisipasi terhadap interaksi di masa depan (Littlejohn \& Foss, 2011). Insentif yang diterima dalam bentuk penerimaan sosial, dukungan positif dapat mengurangi ketidakpastian yang dimiliki mantan narapidana. Mantan narapidana berada pada posisi terjadinya deviasi/ penyimpangan dari perilaku dan sikap sehingga mereka akan mengumpulkan informasi yang dapat mengurangi ketidakpastian mereka pada lingkungan sosialnya. Selanjutnya, mantan narapidana terdorong untuk mengurangi ketidakpastian agar mendapatkan dukungan dan penerimaan sosial, serta pengembangan hubungan yang lebih intensif di masa depan.
Spesifikasi temuan penelitian adalah cara atau strategi yang dilakukan untuk mengurangi ketidakpastian adalah strategi pasif (passive strategy) dan strategi aktif (active strategy). Strategi pasif berdasarkan temuan penelitian berkaitan dengan tingginya kegelisahaan dan ketidakpastian yang mereka terima terhadap perilaku individu tinggi maka mereka akan menarik diri dan bersikap pasif. Sebaliknya, strategi aktif akibat rendahnya tingkatan kegelisahan dan ketidakpastian tinggi menyebabkan mereka cenderung akan membuka membuka diri dan aktif dalam berinteraksi dan berkomunikasi dalam kelompok budaya Bugis Makassar.

Faktor siri' dalam diri mantan narapidana, keluarga, dan masyarakat Bugis Makassar untuk menerima identitas mereka masih menjadi faktor penghambat dalam berinteraksi dan berkomunikasi dengan budaya Bugis Makassar. Dalam falsafah masyarakat Bugis Makassar siri' merupakan perasaan malu atau harga diri dalam diri mantan narapidana. Budaya siri' dalam masyarakat Bugis Makassar memiliki nilai filosofi untuk "Narekko degaga siri'mu, inrengko siri'."Artinya, jika sesorang tidak memiliki perasaan malu maka pinjamlah siri' kepada orang yang masih melekat nilainilai siri' dalam dirinya. Atau "Narekko engka siri'mu, aja' mumapakasiri'-siri'. Artinya, jika seseorang masih memiliki rasa malu sebaiknya jangan mempermalukan diri dan keluarga.

\section{SIMPULAN}

Hasil penelitian mengidenfikasi kasus mantan narapidana yang cenderung tertutup berkomunikasi dalam kelompok Bugis Makassar. Pola kegelisahan dan ketidakpastian menyebabkan mantan narapidana menggunakan strategi mengurangi ketidakpastian yakni, strategi pasif (passive strategy) ditandai penarikan diri dan sikap pasif dan strategi aktif (active strategy) membuka diri dan aktif dalam berinteraksi dan berkomunikasi dalam kelompok budaya Bugis Makassar.

Asumsi hasil representasi kategorisasi dalam penelitian menunjukkan adanya tingkat kegelisahan dan ketidakpastian mantan narapidana cenderung berkategori tinggi. Artinya bahwa semakin tinggi kegelisahan dan ketidakpastian mantan narapidana, maka strategi pasif menjadi pilihannya. Sebaliknya, 
semakin rendah tingkat kegelisahan dan ketidakpastian maka strategi aktif untuk lebih terbuka mengungkapkan diri dengan lingkungan sekitarnya.

\section{DAFTAR PUSTAKA}

Ardilla, F., \& Herdiana, I. (2013). Penerimaan diri pada narapidana wanita. Jurnal Psikologi Kepribadian Dan Sosial, 2(1), 1-7.

Arfianti, E. (2006). Analisis kriminologi terhadap kejahatan kekerasan yang dilakukan oleh perempuan di kota Makassar. Universitas Hasanuddin.

Azani. (2012). Gambaran psychlogical wellbeing mantan narapidana. Jurnal Emphaty, 1(2).

Coyle, A. (2009). A human rights approach to prison management. Criminal Behaviour and Mental Health. London: International Center for Prison Studies. https://doi. org/10.1002/cbm.532

Creswell, J. W. (2014). Research design: qualitative, quantitative, and mixed methods approach (4th ed.). London: Sage Publication, Inc.

Denzin, N. K., \& Lincoln, Y. S. (2009). Handbook of Qualitative Research (Second). London: Sage Publication, Inc.

Dynes, W. R., \& Donaldson, S. (Eds.). (1992). Homosexuality and government, politics and prisons. New York \& London: Garland Publishing.

Gorgulu, T. (2015). Problems, needs and psychological state of ex-convicts: A qualitative study in a Turkish sample. Journal of Education Research and Behavioral Sciences, 4(3), 110-124.

Griffin, E. (2000). A first look at communication theory. Boston: McGraw-Hill.

Gudykunst, W. B., \& Young, K. Y. (1992). Communicating with strangers: an approach to intercultural communication. New York: McGraw-Hill.

Kurniawati, D. A. (2016). Stigma sebagai suatu ketidakadilan pada mantan narapidana perempuan di masyarakat Surabaya. Universitas Airlangga.

LeBel, T. P. (2012). If one doesn't get you another one will: formerly incarcerated persons' perceptions of discrimination. The Prison Journal, 92(1), 63-87. https://doi.org/https://doi. org/10.1177/0032885511429243

Littlejohn, S. W., \& Foss, K. A. (2011). Theories of human communication. Illinois: Waveland Press.

Makmur, R., Kuswarno, E., Novianti, E., \& Syafirah, A. (2018). Bahasa Minang Pondok dalam komunikasi antarbudaya masyarakat Tionghoa Kota Padang. Jurnal Kajian Komunikasi, 6(2), 133-146.

Mattulada. (1985). Latoa: suatu lukisan analitis terhadap antropologi politik orang Bugis. Yogyakarta: Universitas Gadjah Mada Press.

Mccroskey, J. C. (1982). The communication apprehension perspective. Avoiding Communication: Shyness, Reticence, and Communication, 6(1).

Miles, M. B., Huberman, A. M., \& Saldana, J. M. (2015). Qualitative data analysis: a methods sourcebook (3rd ed.). Thousand Oaks, United States: Sage Publication, Inc. Morissan. (2009). Teori komunikasi organisasi. Bogor: Ghalia Indonesia.

Mulyana, D. (2004). Metodologi penelitian kualitatif: paradigma baru ilmu komunikasi dan ilmu sosial lainnya. Bandung: Remaja Rosdakarya.

Mulyana, D., \& Solatun. (2007). Metode penelitian komunikasi: contoh - contoh penelitian kualitatif dengan pendekatan praktis. Bandung: Remaja Rosda Karya.

Putri, N. E., Hakim, N., \& Yamin, M. (2016). Ecologicall Footprint and Biocapacity Analysis for Flooding Prevention in South Sumatera. Jurnal Mimbar, 32(1), 58-64.

Ritzer, G., \& Goodman, D. J. (2007). Teori sosiologi moderen. Jakarta: Prenada Media Group.

Rivlin, A., Hawton, K., Marzano, L., \& Fazel, S. (2010). Psychiatric disorders in male prisoners who made near-lethal suice attempts: case-control study. The British Journal of Psychiatry, 197(4), 313-319. https://doi.org/https://doi.org/10.1192/bjp. bp. 110.077883

Sari, R. A. V. Y., Wati, Y. R., \& Rahmawaty, I. (2014). Perbandingan tingkat depresi antara narapidana non-residivis dan residivis di lembaga pemasyarakatan kelas II A Banceuy. In Pendidikan Dokter. Bandung: 
Pusat Penerbitan Universitas (P2U) Widayati, L. S. (2012). Rehabilitasi Universitas Islam Bandung (Unisba). narapidana dalam overcrowded lembaga Retrieved from http://karyailmiah.unisba. ac.id/index.php/dokter/article/view/1862 pemasyarakatan. Jurnal Negara Hukum, 3(2), 201-226.

Styker, S. (2000). Self, identity and social movements. Minneapolis: University of Minnesota Press.

West, R., \& Turner, L. H. (2009). Introducing communication theory: analysis and application (6th ed.). Washington: McGraw-Hill Humanities.

Wuryansari, R., \& Subandi. (2019). Mindfulness for prisoners (mindfulners) untuk menurunkan depresi pada narapidana. Gadjah Mada Journal of Professional Psychology, 5(2).

Yin, R. K. (2008). Case study research: design and methods. Illionis: Sage Publications, 